\title{
Correction to: Whole lung tissue is the preferred sampling method for amplicon- based characterization of murine lung microbiota
}

Jennifer M. Baker ${ }^{1,2}$, Kevin J. Hinkle ${ }^{2}$, Roderick A. McDonald ${ }^{2}$, Christopher A. Brown², Nicole R. Falkowski², Gary B. Huffnagle ${ }^{1,2,3,4}$ and Robert P. Dickson ${ }^{1,2,5^{*}}$

Correction to: Microbiome 9, 99 (2021)

https://doi.org/10.1186/s40168-021-01055-4

Following the publication of the original article [1], the author reported that there were corrections not correctly carried out. On page 4, two occurences of $30,000 \mathrm{rpm}$ should have read 13,000 rpm

The original article has been updated.

\begin{abstract}
Author details
${ }^{1}$ Department of Microbiology and Immunology, University of Michigan Medical School, Ann Arbor, Ml 48109, USA. ${ }^{2}$ Department of Internal Medicine, Division of Pulmonary and Critical Care Medicine, University of Michigan Health System, 6220 MSRB III/SPC 5642, 1150 W. Medical Center Dr, Ann Arbor, MI 48109-5642, USA. ${ }^{3}$ Department of Molecular, Cellular, \& Developmental Biology, University of Michigan, Ann Arbor, MI 48109, USA. ${ }^{4}$ Mary H. Weiser Food Allergy Center, University of Michigan Medical School, Ann Arbor, Ml 48109, USA. ${ }^{5}$ Michigan Center for Integrative Research in Critical Care, Ann Arbor, MI, USA.
\end{abstract}

Published online: 04 July 2021

\section{Reference}

1. Baker JM, Hinkle KJ, McDonald RA, et al. Whole lung tissue is the preferred sampling method for amplicon-based characterization of murine lung microbiota. Microbiome. 2021;9:99 https://doi.org/10.1186/s40168-021-01 055-4.

\footnotetext{
The original article can be found online at https://doi.org/10.1186/s40168021-01055-4

* Correspondence: rodickso@med.umich.edu

'Department of Microbiology and Immunology, University of Michigan Medical School, Ann Arbor, MI 48109, USA

${ }^{2}$ Department of Internal Medicine, Division of Pulmonary and Critical Care

Medicine, University of Michigan Health System, 6220 MSRB III/SPC 5642,

1150 W. Medical Center Dr, Ann Arbor, MI 48109-5642, USA

Full list of author information is available at the end of the article
}

(c) The Author(s). 2021 Open Access This article is licensed under a Creative Commons Attribution 4.0 International License, which permits use, sharing, adaptation, distribution and reproduction in any medium or format, as long as you give appropriate credit to the original author(s) and the source, provide a link to the Creative Commons licence, and indicate if changes were made. The images or other third party material in this article are included in the article's Creative Commons. licence, unless indicated otherwise in a credit line to the material. If material is not included in the article's Creative Commons licence and your intended use is not permitted by statutory regulation or exceeds the permitted use, you will need to obtain permission directly from the copyright holder. To view a copy of this licence, visit http://creativecommons.org/licenses/by/4.0/ The Creative Commons Public Domain Dedication waiver (http://creativecommons.org/publicdomain/zero/1.0/) applies to the data made available in this article, unless otherwise stated in a credit line to the data. 